VISION: Journal of Indian Taxation Volume 4, Issue 1, January-June 2017, pp. 40-50 doi: 10.17492/vision.v4i01.9992

\title{
An Analysis of Trends and Patterns of Income Tax in India
}

\author{
Amit Kumar Singh*, Rohit Kumar Shrivastav** and Lovleen Gupta***
}

\begin{abstract}
Taxes always occupy an important and strategic place in the development of an economy specially the developing or emerging economies. The present paper analyses patterns and trends in income tax of India. The data shows that the overall tax burden in the financial year 2004-05 was $28.67 \%$ which means that only $71.33 \%$ was available to people for consumption. However, the total tax burden in the financial year 2015-16 dropped to $18.67 \%$ and the income available for consumption was $81.33 \%$. The trend analysis of growth rate in the first slab shows increasing trend from financial year 200405 to financial year 2010-11 i.e., to the level of 3300\%. Thereafter, it went on decreasing from $3300 \%$ to $3100 \%$ to the lower level of $2900 \%$ in the financial year 2015-16. The second tax slab for $20 \%$ is showing an upward trend. The third tax slab for $30 \%$ has seen a declining growth rate from the level of $7.4 \%$ to $62.96 \%$. Therefore we can interpret that the government intends to reduce the tax liability of tax payer and thus improve the standard of living of tax payers by allowing them more disposable income.
\end{abstract}

Keywords:Income tax; Trend analysis; Personal income; Direct taxes; Government revenue.

\subsection{Introduction}

India is having federal structure of constitution and so as the tax levying authority. In India, the tax levying authority is working on two way system of state government and central governments. Central government basically levies direct taxes like personal income tax and the corporate tax; indirect taxes such as excise duty, service tax and customs and along with that the sales tax on the inter-state transactions (CST).

\footnotetext{
*Corresponding author; Associate Professor, Department of Commerce, Delhi School of Economics, University of Delhi, Delhi, India. (Email id: amitipo10@gmail.com)

** Ph. D Research Scholar, Department of Commerce, Delhi School of Economics, University of Delhi, Delhi, India (Email id: e-mail: rohitkshrivastav@gmail.com)

***Assistant Professor, Department of Commerce, Hindu College, University of Delhi, Delhi, India. (Email id: lovleen15_gupta@yahoo.co.in)
} 
The states government levies state sales taxes, VAT on goods and various other local taxes. Since 1991, our economy's tax structure has been rationalised substantially. At state level, the introduction of VAT in 2005 in 24 States and Union Territories has been the main reform although it was implemented after delay of ten years. Changes at central level include lowering CIT rates, reducing customs and excise duties, broadening the tax base in case of services and extending a form of VAT to some industries.

A major source for government to earn revenue in India is direct taxes. The Income Tax Act, 1961 covers every person (including individuals, Hindu Undivided Family, companies, firms, cooperative societies and artificial judicial persons) whose net total income becomes more than exemption limit and therefore every person is liable to pay income tax at prescribed rates. Payment of tax is an enforced contribution and not voluntary in nature and that is why tax is better known as financial charge. Despite the fact that money provided by taxation is used to carry out many activities for the betterment and development of the economy, it usually gives a feeling of displeasure to every tax payer. Actually, the problem is that tax payers do not want that their hard earned money to be taken away from them. There is historical evidence that there is always a struggle between the tax payer and tax collector. This may emerge due to the irrationality in the personal income tax structure. The tax rates, tax base and tax slabs in personal income tax schedule were exorbitantly higher by any standards during the period under review. The need for rationalisation of the tax structure was felt long back but very little reform has been seen so far.

\subsection{Review of Literature}

This section reviews some existing studies that have examined various aspects of income tax trends in India. Rajeshwari and Mary (2014) examined the trends and pattern of the Indian income tax collection as well as the revenue behaviour. They argued that since economic crisis of 1991 led structural tax reforms in India with the main purpose of correcting the fiscal imbalance, therefore it is forced to reduce disparity in income tax. Many steps have been taken for improving ratio of tax-GDP by augmenting the collections of tax with the help of improvement in tax administration with support of facilitating public interface and leveraging technology, where required, through appropriate training and capacity building. They further discussed origin and evolution of income tax, income tax structure, expenditure incurred by the Indian government to collect taxes and direct tax GDP ratio and found that direct tax collection as a percentage of GDP is doubled as a result of improved tax administration and better tax compliance. 
Gupta (2013) threw light on prevailing personal income tax structure in India and analysed issues relating to the high tax burden on people falling under low and medium income groups. It was observed that a need is felt to bring out major reforms in the structure of personal income tax by lowering of rate of tax, broadening exemption limits, simplify overall tax procedure and reorganising different income tax slabs for encouraging the persons to follow the tax laws. Jha (2013) made an attempt to study the impact of old and reformed tax structure as per FRBMA (The Fiscal Responsibility and Budget Management Act, 2003) Road Map. Their impact is analysed on the mode of financing of companies and different types of investments. It was found that Indian tax system has not fully evolved. Hence, we should not make any decisions based on a knee jerk reaction to the changes in the economy.

Parkash and Sidhu (2011) analysed the impact of the direct tax reforms on the Indian economy in the context of various economic indicators and then compared it with the pre-reform period. Their study revealed that tax reforms introduced during the period of post-liberalisation could not generate the results as desired. Reduction in direct tax rates could not be lead to better tax compliance. They further concluded that there is a very strong need to review the tax reform policies being followed in the postliberalisation period. Mitra (2011) attempted to throw light on the effect of direct tax codes on the individuals and corporates. It was found during the study that although, the purpose of direct tax code is not only to reduce the lengthy amendments in tax law but also to facilitate an ease of dealing with tax laws. Hence, it was discovered that the direct tax codes will help the individuals and corporates in compliance and hence will result into higher tax collection.

Aamir et al. (2011) explored about direct taxes and indirect taxes for the purpose of comparing these types of taxes in India and Pakistan. They collected tax revenue under heads of indirect and direct taxes. The results showed that Pakistan is generating more tax revenue through indirect taxes whereas India is generating from direct taxes. They further compared two regression equations and standardised betas and came to know that India is earning more revenue by levying direct taxes whereas Pakistan generates more revenue by levying indirect taxes.

Das (2011) tried to develop a political-economy model to show how political imperatives lead to reforms in administering direct tax collection. A static, political-gain approach was used to model employment in the tax collection sector and then the implications of an increase in revenue pressure were derived through a comparative statics method. It was found that as revenue pressure increases, the 'political value' in terms of granting employment falls and thus efficiency resulting from purely political motives decreases. 
Gupta (2009) examined the trends and responsiveness of personal income tax in India. The study attempts to find out the responsiveness of the personal income taxation with respect to the national income with the inclusion of various indicators of income. It is observed that trends in personal income tax showed reforms that had a favourable impact on growth of personal income tax. The major factors that can be cited for increase in revenue responsiveness of personal income tax are reduction in the number of tax slabs, increasing compliance through wider coverage of tax assesses in terms of PAN, TDS and TIN, reduction in top marginal rate of personal income tax and increase in the number of tax assessees by way of simplification of tax structure. Zee (2006) investigated the possibility of crowding-out of regular development aid by global taxes. The paper models cross-country interactions in aid giving using a simple Cournot-Nash framework. The paper argues that global taxes could lead to an increase in aid-cum-tax revenue if such taxes produce a globally net positive income effect. Whether this condition can be satisfied is very much an open empirical issue. An alternative to global taxes is cooperative aid-giving among donors, which this paper shows will always result in more global aid.

Pandey (2006) explored the impact of policy initiatives and directions on the direct tax reforms in India. The study was conducted for ten year period. It was found in the study that polices are directions affect the direct tax structure and environment in India. If the policy introduced by the government is positive then direct tax is more effective in order to raise money collection and if the policy introduced by the government is not tax environment friendly then people will try to evade taxes by doing financial planning or taking any other alternative way of skipping tax liability. Rao (2005) examined the achievement, challenges and reforms in tax system in India. It was in the study that India has transformed tax system from narrow based to more complicated but far more efficient. Year on year basis thrust and direction was on the improvement of revenue and productivity. There has been a trend of narrow based for personal income tax. Although Sales tax is there but its reform has just only begun and there is a lot more to be done. These reforms aim to have more revenues and thereby providing elbow room necessary for the calibration of future reforms.

Aggarwal (1991) developed a technique for estimating the effect of a change in inequality in the distribution of income on the yield of personal income tax. The technique is applied to estimate the effect of income inequality on the yield of personal income tax in India. It is found that, for a given tax schedule, an increase (decrease) in inequality in the distribution of income among the taxpayers increases (decreases) yield of personal income tax in India. Further, the study brings out that in India, during 1966- 
67 to $1983-84$, inequality in taxable income was marked by a declining trend, and this had substantial negative impact on elasticity of the tax.

\subsection{Objectives of the Study}

The primary objectives of the study are to analyse the trend of personal income tax structure in India, and to determine the present scenario and future prospects of prevailing income tax structure

\subsection{Research Design and Methodology}

\subsection{Scope of the study and methodology}

The present study is exploratory as well as descriptive in nature. The study has been conducted considering the direct taxes, more precisely the personal income tax. Moreover, the study has broadly focused on the performance of the tax structure introduced by the government from time to time in order to improve the country's revenue base and for this purpose last 12 financial years have been taken starting from 2004-2005 to 2014-2015.

\subsection{Sources of data}

Data has been gathered from secondary sources during course of the study. The data is mainly collected from Ministry of Finance and the Finance Bills introduced by the government from time to time. Various contents based on indirect taxes, direct taxes, reports in newspapers, circulars of Central Board of Direct Taxes (CBDT), Public Finance statistics from 'Economic Survey' of Government of India, research papers in journals and magazines, various internet sites and other relevant literature were consulted. Guidance of the experts in the field and view of public is also considered for carrying out the study. Along with this, the website of Yahoo finance and Google Finance was also used as a source of information. The secondary data and other pertinent literature available on the subject has been compiled from published/unpublished materials, documents and internet sources through extensive desk work.

\subsection{Data Analysis and Interpretation}

Table 1 shows the basic exemption limit of the tax payers from time to time starting from the year 2004-05 to financial year 2015-16. It is very clear from the Table that there has been a difference between male and female tax payer's basic exemption 
limit. However, the senior citizens have also been given a higher amount of exemption limit compared to males and females. It is to be noted that in year 2011-12, a new category called 'very senior citizen' has been added for people above 80 years. Now we have two types of senior citizens: 'senior citizen' up to 60 years of age, and 'very senior citizen' in the age of 80 years or above. The exemption limit for very senior citizen is Rs. $5,00,000$ which tends to be higher. It has been kept by the government keeping in view the economic conditions of 'very senior citizen' and their expenses on the commodities specially the medical expenses. In the financial year 2012-13, the government has also made no difference between male and female tax payer's slab.

Table 1: Basic Tax Exemption Limit for Male, Female, Senior Citizen and Very Senior Citizen

\begin{tabular}{|c|c|c|c|c|}
\hline Financial Year & Male & Female & Senior Citizen & Very Senior Citizen \\
\hline $2004-05$ & 50,000 & 50,000 & 50,000 & N.A. \\
\hline $2005-06$ & 50,000 & 50,000 & 50,000 & N.A. \\
\hline $2006-07$ & $1,00,000$ & $1,35,000$ & $1,85,000$ & N.A. \\
\hline $2007-08$ & $1,10,000$ & $1,45,000$ & $1,95,000$ & N.A. \\
\hline $2008-09$ & $1,50,000$ & $1,80,000$ & $2,25,000$ & N.A. \\
\hline $2009-10$ & $1,60,000$ & $1,90,000$ & $2,40,000$ & N.A. \\
\hline $2010-11$ & $1,60,000$ & $1,90,000$ & $2,40,000$ & N.A. \\
\hline $2011-12$ & $1,80,000$ & $1,90,000$ & $2,50,000$ & $5,00,000$ \\
\hline $2012-13$ & $2,00,000$ & $2,00,000$ & $2,50,000$ & $5,00,000$ \\
\hline $2013-14$ & $2,00,000$ & $2,00,000$ & $2,50,000$ & $5,00,000$ \\
\hline $2014-15$ & $2,50,000$ & $2,50,000$ & $3,00,000$ & $5,00,000$ \\
\hline $2015-16$ & $2,50,000$ & $2,50,000$ & $3,00,000$ & $5,00,000$ \\
\hline
\end{tabular}

Source: Department of Revenue, Ministry of Finance (http://dor.gov.in/direct-tax)

Figure 1 depicts the trend of basic exemption limit/liability for common tax payers. It is very clear from the Figure that the basic exemption limit for all the categories of tax payers have been increasing from year to year and in the last four financial year, the graph is showing a very big change in the basic exemption limit. Therefore, we can say that the government has continuously uplifted the scale and level of basic exemption limit. Table 2 represents growth in the tax liability during the financial year staring from 2004-05 to 2015-16. It is showing various tax liabilities for the various categories of tax limit and for the various financial years. This Table is pretty clear about the increase in the liability in the tax bracket of $10 \%$ and for the $20 \%$ too. 
46 | VISION: Journal of Indian Taxation, Volume 4, Issue 1, January-June 2017

Figure 1: Trend for Basic Exemption Limit/Liability for Common Tax Payers

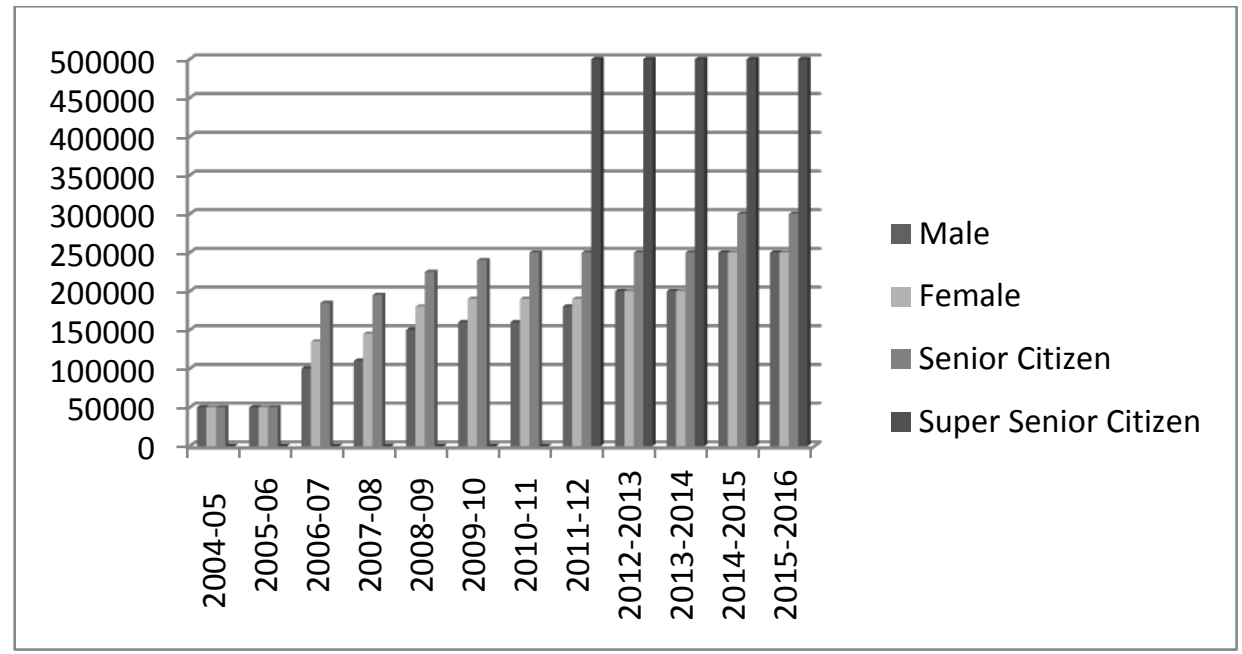

Source: Based on Table 1

Table 2: Growth in Tax Liability during 2004-05 to 2015-16

\begin{tabular}{|c|c|c|c|c|c|c|c|c|c|}
\hline $\begin{array}{l}\text { Financial } \\
\text { Year }\end{array}$ & Income & Rate & Liability & Income & Rate & Liability & Income & Rate & Liability \\
\hline 2004-05 & $\begin{array}{l}50,001- \\
60,000\end{array}$ & $10 \%$ & 1,000 & $\begin{array}{l}60,001- \\
150,000\end{array}$ & $20 \%$ & 18,000 & $\begin{array}{l}150,001- \\
15,00,000\end{array}$ & $30 \%$ & $4,05,000$ \\
\hline $2005-06$ & $\begin{array}{l}100,001- \\
150,000\end{array}$ & $10 \%$ & 5,000 & $\begin{array}{l}150,001- \\
250,000\end{array}$ & $20 \%$ & 20,000 & $\begin{array}{l}250,001- \\
15,00,000\end{array}$ & $30 \%$ & $3,75,000$ \\
\hline 2006-07 & $\begin{array}{l}100,001- \\
150,000\end{array}$ & $10 \%$ & 5,000 & $\begin{array}{l}150,001- \\
250,000\end{array}$ & $20 \%$ & 20,000 & $\begin{array}{l}250,001- \\
15,00,000\end{array}$ & $30 \%$ & $3,75,000$ \\
\hline 2007-08 & $\begin{array}{l}110,001- \\
150,000\end{array}$ & $10 \%$ & 4,000 & $\begin{array}{l}150,001- \\
250,000\end{array}$ & $20 \%$ & 20,000 & $\begin{array}{l}250,001- \\
15,00,000\end{array}$ & $30 \%$ & $3,75,000$ \\
\hline 2008-09 & $\begin{array}{l}150,001- \\
300,000\end{array}$ & $10 \%$ & 15,000 & $\begin{array}{l}300,001- \\
500,000\end{array}$ & $20 \%$ & 40,000 & $\begin{array}{l}500,001- \\
15,00,000\end{array}$ & $30 \%$ & $3,00,000$ \\
\hline 2009-10 & $\begin{array}{l}160,001- \\
300,000\end{array}$ & $10 \%$ & 14,000 & $\begin{array}{l}300,001- \\
500,000\end{array}$ & $20 \%$ & 40,000 & $\begin{array}{l}500,001- \\
15,00,000\end{array}$ & $30 \%$ & $3,00,000$ \\
\hline 2010-11 & $\begin{array}{l}160,001- \\
500,000\end{array}$ & $10 \%$ & 34,000 & $\begin{array}{l}500,001- \\
800,000 \\
\end{array}$ & $20 \%$ & 60,000 & $\begin{array}{l}800,001- \\
15,00,000\end{array}$ & $30 \%$ & $2,10,000$ \\
\hline 2011-12 & $\begin{array}{l}180,001- \\
500,000 \\
\end{array}$ & $10 \%$ & 32,000 & $\begin{array}{l}500,001- \\
800,000\end{array}$ & $20 \%$ & 60,000 & $\begin{array}{l}800,001- \\
15,00,000\end{array}$ & $30 \%$ & $2,10,000$ \\
\hline 2012-13 & $\begin{array}{l}2,00,001- \\
5,00,000\end{array}$ & $10 \%$ & 30,000 & $\begin{array}{l}5,00,001- \\
10,00,000\end{array}$ & $20 \%$ & $1,00,000$ & $\begin{array}{l}10,00,001- \\
15,00,000\end{array}$ & $30 \%$ & $1,50,000$ \\
\hline 2013-14 & $\begin{array}{l}2,00,001- \\
5,00,000\end{array}$ & $10 \%$ & 30,000 & $\begin{array}{l}5,00,001- \\
10,00,000\end{array}$ & $20 \%$ & $1,00,000$ & $\begin{array}{l}10,00,001- \\
15,00,000\end{array}$ & $30 \%$ & $1,50,000$ \\
\hline 2014-15 & $\begin{array}{l}2,50,001- \\
5,00,000\end{array}$ & $10 \%$ & 30,000 & $\begin{array}{l}5,00,001- \\
10,00,000\end{array}$ & $20 \%$ & $1,00,000$ & $\begin{array}{l}10,00,001- \\
15,00,000\end{array}$ & $30 \%$ & $1,50,000$ \\
\hline 2015-16 & $\begin{array}{l}2,50,001- \\
5,00,000\end{array}$ & $10 \%$ & 30,000 & $\begin{array}{l}5,00,001- \\
10,00,000\end{array}$ & $20 \%$ & $1,00,000$ & $\begin{array}{l}10,00,001- \\
15,00,000\end{array}$ & $30 \%$ & $1,50,000$ \\
\hline
\end{tabular}

Source: Income Tax Slab Based on Finance Act 
However, it is also to be noted that the third slab of $30 \%$ tax liability is showing something else. The third slab is showing that the absolute liability amount has been declining over the years. Since tax slab of $10 \%$ is showing increase in the tax liability, we may conclude that the increase in the tax slab $10 \%$ liability is just because of the increase in the income also. Although the government tried to increase the basic exemption limit but the slab second i.e., 20\% tax slab is also showing the upward movement in the liability of the tax for assesses.

Table 3 presents the overall percentage of tax burden of the tax liability of general tax payer. It is very clear from the Table that in the beginning period of our study i.e., 2004-05 the tax liability of general tax payer was as high as $28.67 \%$ but in the later years, the exemption tax limit kept on increasing and the overall tax liability of tax payers decreased and it fell down from $28.67 \%$ to $18.67 \%$. It is very interesting to note that the burden of the taxes on the payers has declined over the years and this shows that government's intention is to provide more purchasing capacity to tax payers so that they could spend more on their personal well-being and their standard of living could be uplifted. Since the total tax burden for a person having income of Rs.15,00,000 is coming down to $18.67 \%$ that is a very positive sign for the tax payers who had been paying a hefty amount of taxes earlier and now they need to pay lesser amount of tax out of their hard earned money.

Table 3: Overall Tax Burden on Taxpayers

\begin{tabular}{|l|l|l|l|r|l|r|}
\hline $\begin{array}{l}\text { Financial } \\
\text { Year }\end{array}$ & $\begin{array}{l}\text { Tax load } \\
\text { on } \\
\text { first slab } \\
\text { (In Rs.) }\end{array}$ & $\begin{array}{l}\text { Tax load on } \\
\text { second slab } \\
\text { (In Rs.) }\end{array}$ & $\begin{array}{l}\text { Tax load } \\
\text { on } \\
\text { third slab } \\
\text { (In Rs.) }\end{array}$ & $\begin{array}{l}\text { Total tax } \\
\text { load (In Rs.) }\end{array}$ & $\begin{array}{l}\text { Total } \\
\text { taxable } \\
\text { Income (In } \\
\text { Rs.) }\end{array}$ & $\begin{array}{l}\text { Tax } \\
\text { liability(in } \\
\text { \%) }\end{array}$ \\
\hline $2004-05$ & 1,000 & 18,000 & $4,05,000$ & 424,000 & $15,00,000$ & 28.67 \\
\hline $2005-06$ & 5,000 & 20,000 & $3,75,000$ & 400,000 & $15,00,000$ & 26.67 \\
\hline $2006-07$ & 5,000 & 20,000 & $3,75,000$ & 400,000 & $15,00,000$ & 26.67 \\
\hline $2007-08$ & 4,000 & 20,000 & $3,75,000$ & 399,000 & $15,00,000$ & 26.6 \\
\hline $2008-09$ & 15,000 & 40,000 & $3,00,000$ & 355,000 & $15,00,000$ & 23.67 \\
\hline $2009-10$ & 14,000 & 40,000 & $3,00,000$ & 354,000 & $15,00,000$ & 23.6 \\
\hline $2010-11$ & 34,000 & 60,000 & $2,10,000$ & 304,000 & $15,00,000$ & 20.26 \\
\hline $2011-12$ & 32,000 & 60,000 & $2,10,000$ & 302,000 & $15,00,000$ & 20.13 \\
\hline $2012-13$ & 30,000 & $1,00,000$ & $1,50,000$ & 280,000 & $15,00,000$ & 18.67 \\
\hline $2013-14$ & 30,000 & $1,00,000$ & $1,50,000$ & 280,000 & $15,00,000$ & 18.67 \\
\hline $2014-15$ & 30,000 & $1,00,000$ & $1,50,000$ & 280,000 & $15,00,000$ & 18.67 \\
\hline $2015-16$ & 30,000 & $1,00,000$ & $1,50,000$ & 280,000 & $15,00,000$ & 18.67 \\
\hline
\end{tabular}

Source: Based on Table-1 
Table 4 is very clear about slab first, second and third behaviour starting from the financial year 2004-05 to financial year 2015-16. The Table shows the trend analysis of growth rate In the first slab, the growth rate was drastically increasing from financial year 2004-05 to financial year 2010-11 i.e., to the level of 3300\%. But lateron it went on decreasing from $3300 \%$ to $3100 \%$ to the lower level of $2900 \%$ in the financial year 2015-16. The second tax slab for $20 \%$ is showing an upward trend in growth rate. It was $11.11 \%$ in the financial year $2005-06$ to $455.55 \%$ in the financial year $2015-16$.It is very interesting to see that in the third tax slab for $30 \%$, the growth rate has been declining from the level of $-7.4 \%$ to $-62.96 \%$. It is a clear cut indication that the government has given a lot of relaxation to the persons earning above average level of income.

Table4: Trend Analysis of Growth Rate in First, Second and Third Tax Slab

\begin{tabular}{|c|c|c|c|}
\hline $\begin{array}{c}\text { Financial } \\
\text { Year }\end{array}$ & $\begin{array}{c}\text { Growth in First Tax } \\
\text { Slab for 10\% (in \%) }\end{array}$ & $\begin{array}{c}\text { Growth in Second Tax } \\
\text { Slab for 20\% (in \%) }\end{array}$ & $\begin{array}{c}\text { Growth in Third Tax } \\
\text { Slab for 30\% (in \%) }\end{array}$ \\
\hline $2004-05$ & --- & --- & --- \\
\hline $2005-06$ & 400 & 11.11111 & -7.4 \\
\hline $2006-07$ & 400 & 11.11111 & -7.4 \\
\hline $2007-08$ & 300 & 11.11111 & -7.4 \\
\hline $2008-09$ & 1,400 & 122.2222 & -25.92 \\
\hline $2009-10$ & 1,300 & 122.2222 & -25.92 \\
\hline $2010-11$ & 3,300 & 233.3333 & -48.14 \\
\hline $2011-12$ & 3,100 & 233.3333 & -48.14 \\
\hline $2012-13$ & 2,900 & 455.555 & -62.96 \\
\hline $2013-14$ & 2,900 & 455.555 & -62.96 \\
\hline $2014-15$ & 2,900 & 455.555 & -62.96 \\
\hline $2015-16$ & 2,900 & 455.555 & -62.96 \\
\hline
\end{tabular}

Source: Based on Table 1

\subsection{Conclusion and Suggestions}

The major source of earning revenue from direct taxes in India is income tax. Despite the fact that money provided by taxation is used to carry out many activities for the betterment and development of the economy, still it usually gives feeling of displeasure to every tax payer. Actually, the problem is that tax payers do not want that their hard earned money should be taken away from them, most probably due to the high rate of taxes imposed on the personal income of assesses. It is being believed that there is a struggle between tax collector and tax payer. The study conducted is showing that from 
the financial year 2004-05 the tax burden was much more in the context of income. But the exemption limit was different for the different assesses (male, female and senior citizen). In financial year 2011-12, a new category very senior citizen is added and their tax exemption limit was higher than other counterparts.

The growth rate for tax slab first (10\%) has been showing an upward trend so as the second slab (20\%). However, in the case of third slab (30\%), it is showing the reverse trend. As the financial years are keep on moving, the absolute amount of tax for third slab is declining. Therefore, it is basically reducing the overall tax burden on the person having higher income. The overall tax burden in the financial year 2004-05 was $28.67 \%$ that means only $71.33 \%$ is available to person for consumption. However, the total tax burden in the financial year 2015-16 has dropped to $18.67 \%$ and income available for personal consumption is higher. This is a good sign of improving the standard of living of the assesses who were paying hefty amount of taxes earlier and now they are required to pay overall lesser amount of taxes in context of their total income.

The trend analysis of growth rate in the first slab shows increasing trend from financial year 2004-05 to financial year 2010-11, i.e., to the level of $3300 \%$. Later on, it went on decreasing from $3300 \%$ to $3100 \%$ to the lower level of $2900 \%$ in the financial year 2015-16. The second tax slab for $20 \%$ is showing an upward trend. The third tax slab for $30 \%$ has seen a declining trend in terms of growth rate from the level of $-7.4 \%$ to $-62.96 \%$. So, it is a clear cut indication that the government has given a lot of relaxation to the persons earning above average level of income. So, the study reflects that although the tax liability of the persons has been increasing in the first slab and second slab but it is declining in the third slab. The overall tax burden is also showing a downward trend therefore we can interpret that the government is showing the intention to reduce the tax liability of tax payer and as a result improve the standard of living of tax payers by allowing them to have more money at their disposal for their personal consumption.

\section{References}

Aamir, M., Qayyum, A., Nasir, A., Hussain, S., Khan, M.A. \&, Butt, S. (2011). Determinants of tax revenue: A comparative study of direct taxes and indirect taxes of Pakistan and India. International Journal of Business and Social Science, 2(19), 173178.

Agarwal, P. K. (1991). Income inequality and elasticity of personal income tax. Economic and Political Weekly, 26(9), 216-222. 
50 | VISION: Journal of Indian Taxation, Volume 4, Issue 1, January-June 2017

Das, S. P. (2011). The political economy of revenue pressure and tax collection efficiency. Indian Growth and Development Review, 4(1), 38-52.

Gupta, R. (2013). Personal income tax structure in India: An evaluation. Pacific Business Review International, 5(7), 1-6.

Gupta, A. (2009). The trends and responsiveness of personal income tax in India. IGIDR Proceedings/Project Reports Series, 4(1), 62-29. Retrieved from: http://www.igidr.ac.in/pdf/publication/PP-062-29.pdf

Jha, A. (2013). Tax structure in India and effect on corporates. International Journal of Management and Social Sciences Research, 2(10), 80-82.

Mitra, D. (2011). Direct tax code: Effect on individuals and corporate. Indian Journal of Commerce, 64(2), 20-27.

Prakash, O. \&, Sindhu, A. (2011). Direct tax reforms in India: A comparative study of pre and post liberlisation periods. IUP Journal of Public Finance, 9(1), 54-76.

Pandey, M. (2006). Direct tax reforms in India: Policy initiatives and directions. Patiala, Punjab: M.M. Publisher.

Rao, M.G. (2005). Tax system reform in India: Achievements and challenges ahead. Asia Pacific Development Journal, 16(6), 993-1011.

Rajeshwari, K. \&, Mary, M.T.C. (2014). The trend and pattern of income taxation in India. International Journal of Business and Administration Research Review, 2(5), 118124.

Zee, H.H. (2006).A note on global taxes and aid for development. Journal of Economic Studies. 33(1), 5-11. 